\title{
Hubungan Antara Motivasi dengan Perilaku Perawat dalam Mendokumentasikan Asuhan Keperawatan di Instalasi Rawat Inap RSUD Wates Kulon Progo
}

\author{
Hasmawati ${ }^{1}$, Sri Werdati ${ }^{1}$, Fatma Siti Fatimah ${ }^{1}$ \\ 1 Universitas Alma Ata, Yogyakarta, Indonesia \\ Email: hasma1609@gmail.com
}

\begin{abstract}
Abstrak
Dokumentasi merupakan bagian penting dari praktik keperawatan sebagai bentuk komunikasi efektif antar tenaga kesehatan professional lainnya. Proses pendokumentasian asuhan keperawatan dirumah sakit dapat dipengaruhi oleh faktor lingkungan rumah sakit dan dari faktor perawat. Faktor dari rumah sakit mencakupi bahasa, format dokumentasi, cara mengkomunikasikan proses dokumentasi serta kebijakan rumah sakit terhadap standar proses dokumentasi, sedangkan faktor dari perawat dapat berupa motivasi dari atasan dan perilaku perawat sendiri dalam mendokumentasikan asuhan keperawatan. Jenis penelitian ini merupakan penelitian kuantitatif dengan metode studi cross sectional. Populasi penelitian ini adalah perawat yang bekerja di instalasi rawat inap di RSUD Wates Kulon progo. Sampel dalam penelitian ini perawat yang melakukan dokumentasi asuhan keperawatan sebanyak 71 sampel cara pengambilan sampel menggunakan total sampel. Pengumpulan data menggunakan kuesioner motivasi dan checklist observasi dokumentasi asuhan keperawatan. Metode yang digunakan dalam mengolah data menggunakan analisis uji alternatif Fisher's. Hasil Penelitian responden dalam penelitian ini menujukkan bahwa terdapat sebagian besar perawat memiliki motivasi dengan kategori tinggi yaitu sejumlah 48 orang $(67,6 \%)$ dan yang memiliki kategori sedang sebanyak 23 orang $(32,4 \%)$. Perilaku perawat berada pada kategori baik berjumlah 63 orang $(88,7 \%)$, dan kategori perilaku kurang berjumlah 5 orang $(11,3 \%)$. Hasil uji statistik menggunakan uji alternatif Fisher's didapatkan nilai p-value sebesar 0,012 yang berarti lebih kecil dari 0,05 . Kesimpulan penelitian ini ada hubungan antara motivasi dengan perilaku perawat dalam mendokumentasikan asuhan keperawatan di RSUD Wates Kulon Progo.
\end{abstract}

Kata Kunci: Motivasi; Perilaku; Dokumentasi Asuhan Keperawatan

The Correlation Between Motivation and Nurse's Behavior in Documenting the Nursing Care in Inpatient Care Installation at Rsud Wates Kulon Progo

\begin{abstract}
Documentation is an essential part of nursing practices which plays role as effective communication between other professional medical workers. The documentation process of nursing care in hospital can be influenced by the hospital environment factor and nurse factor. Hospital factors include language, documentation format, way to communicate the documentation process, and hospital policy towards the documentation process standard. Meanwhile, nurse factors may include motivation from superiors and the nurse's own behavior in documenting the nursing care. This research was a quantitative research which used cross sectional study method. The population of the research consisted of nurses who work at the inpatient installation at the RSUD of Wates Kulon Progo. The samples of the research were 71 nurses who conducted documentation of the nursing care and they were selected by using total sampling technique. The data collection was through motivation questionnaires and nursing care observation sheets. The method used to analyze the data was by using Fisher's alternative test. The respondents of the research showed that the majority of the nurses had motivation in high rating with 48 nurses (67,6\%) and middle rating with 23 nurses $(32,4 \%)$. The nurses'behaviors were in good category with 63 nurses (88,7\%) and insufficient category with 5 nurses $(11,3 \%)$. The statistic test result was found using Fisher's alternative test and obtained 0,012 $p$-value which was smaller than 0,05 $(0<0,05)$. There existed a correlation
\end{abstract}


between motivation and nurse's behavior in documenting nursing care at the RSUD of Wates Kulon Progo.

\section{Keywords: Motivation; Behavior; Nursing Care Documentation}

Received:10/02/2020; Published:01/05/2020

\section{PENDAHULUAN}

Dokumentasi asuhan keperawatan merupakan catatan atau laporan penting yang ditulis tim kesehatan untuk melaksanakan asuhan keperawatan pada pasien yang meliputi data pasien masuk dirumah sakit, riwayat kesehatan dan pemeriksaan, diagnosa keperawatan, rencana tindakan yang akan dilakukan, catatan perkembangan evaluasi dan perencanaan klien pulang (1). Menurut data jurnal keperawatan Indonesia, diperoleh data dengan hasil penelitian pendokumentasian asuhan keperawatan sebanyak (71,6\%) belum lengkap. Masalah di Indonesia dalam pelaksanaan asuhan keperawatan adalah banyak perawat yang belum melakukan pelayanan sesuai pendokumentasian asuhan keperawatan. Pelaksanaan asuhan keperawatan juga tidak disertai pendokumentasian yang lengkap. Fakta menunjukkan bahwa dari 10 dokumentasi asuhan keperawatan, dokumentasi 4 pengkajian hanya terisi $25 \%$, dokumentasi diagnosis keperawatan $50 \%$, dokumentasi perencanaan $37,5 \%$, dokumentasi implementasi 35,5\% dan dokumentasi evaluasi $25 \%$ (2).

Undang-undang RI Nomor 44 Tahun 2009 pasal 52 tentang rumah sakit menyatakan bahwa setiap rumah sakit wajib melakukan pencatatan dan pelaporan semua penyelenggaraan kegiatan rumah sakit dalam bentuk sistem informasi manajemen berupa pencatatan, penyimpanan, pelaporan, dan pemusnahan dalam waktu tertentu sesuai peraturan perundang-undangan (3). PERMENKES No. 148 tahun 2010 dan Undang-undang keperawatan 38 tahun 2014 juga menyebutkan bahwa perawat berwenang melakukan asuhan keperawatan secara sistematis dan sesuai standar. PERMENKES RI No. 48 tahun 2006 tentang standar pelayanan minimal bidang kesehatan menyebutkan bahwa pemberi pelayanan rawat inap adalah dokter dan tenaga perawat yang kompeten minimal D3 keperawatan (3).

Proses pendokumentasian asuhan keperawatan dirumah sakit dapat dipengaruhi oleh faktor lingkungan rumah sakit dan dari faktor perawat. Faktor dari rumah sakit mencakupi bahasa, format dokumentasi, cara mengkomunikasikan proses dokumentasi serta kebijakan rumah sakit terhadap standar proses dokumentasi (2). Sementara dari faktor perawat sendiri dapat dipengaruhi oleh motivasi dan perilaku perawat terhadap proses dokumentasi (9).

Motivasi perawat dapat mempengaruhi keakuratan dari dokumentasi dan kualitas kerja dimana perawat yang kurang termotivasi cenderung kurang tepat dalam menuliskan dokumentasi keperawatan atau mengisi dokumentasi keperawatan yang tidak sesuai dengan Indonesian Journal of Hospital Administration Vol. 3 No.1 
hasil temuan dilapangan (10). Sedangkan perilaku perawat dalam menyikapi proses dokumentasi dapat mempengaruhi kredibilitas dokumentasi keperawatan (9). Kualitas perilaku perawat seperti semangat, komitmen, dan kepedulian perawat dalam melaksanakan dokumentasi keperawatan lebih sulit untuk diketahui secara obyektif, perilaku tersebut cenderung bisa diketahui dari penulisan dokumentasi yang lengkap sehingga terdapat gambaran perilaku perawat selama proses keperawatan (11). Perilaku perawat juga dapat dipengaruhi oleh faktor tingkat pengalaman kerja, motivasi kerja, dan pengalaman kerja dalam penulisan dokumentasi yang lebih efektif, mendetail, dan mudah dimengerti oleh antar profesi kesehatan professional (10).

Berdasarkan penelitian yang dilakukan oleh Josua Edison Mangole pada tahun 2015 menunjukan bahwa perilaku yang baik dengan pendokumentasian yang lengkap sebanyak $(66 \%)$ dan responden yang memiliki perilaku baik dengan pendokumentasian tidak lengkap sebanyak (33,3\%), perilaku kurang baik dengan pendokumentasian lengkap sebanyak $(20 \%)$ dan pendokumentasian yang tidak lengkap sebanyak (80\%). Bahwa hasil dari penelitian tersebut terdapat hubungan yang signifikan antara perilaku perawat dengan pendokumentasian asuhan keperawatan. dokumentasi keperawatan perawatan dalam aspek asesmen, diagnostik aspek, aspek perencanaan, aspek evaluasi, dinyatakan lengkap dengan persentase di atas 70\% di RSUD Wates Kulon Progo (4).

Berdasarkan penelitian yang dilakukan oleh Retyaningsih Ida Yanti pada tahun 2013 menunjukan bahwa sebanyak $(52,8 \%)$ motivasi dalam pendokumentasian asuhan keperawatan tidak baik dan sebanyak (84,9\%) presepsi terhadap supervisi kepala tentang pendokumentasian asuhan keperawatan baik. Dari hasil penelitian tersebut terdapat hubungan yang signifikan antara karakteristik perawat, motivasi dan supervisi dengan kualitas dokumentasi asuhan keperawatan (5).

Undang - undang RI Nomor 44 Tahun 2009 pasal 52 tentang rumah sakit menyatakan bahwa setiap rumah sakit wajib melakukan pencatatan dan pelaporan semua penyelenggaraan kegiatan rumah sakit dalam bentuk sistem informasi menajemen berupa pencatatan, penyimpanan, pelaporan, dan pemusnahan dalam waktu tertentu sesuai dengan peraturan perundang - undangan. Menurut surat keputusan menteri kesehatan RI No. 983/1992, tugas pokok rumah sakit ialah melaksanakan upaya kesehatan secara berdaya guna dengan mengutamakan upaya penyembuhan dan pemulihan yang dilaksanakan secara serasi dan terpadu dengan upaya rumah sakit sebagai unit usaha dibidang jasa terutama untuk pemulihan, rehabilitasi, pemeliharaan, peningkatan, pendidikan dan riset kesehatan memerlukan pengelolaan secara profesional agar mutu pelayanan kepada pasien dan keluarga menjadi baik (2). Permenkes No. 148 tahun 2010 dan undang-undang keperawatan 
38 tahun 2014 juga menyebutkan bahwa perawat berwenang melakukan asuhan keperawatan secara sisitematis dan sesuai standar (3).

\section{BAHAN DAN METODE}

Jenis penelitian ini adalah kuantitatif bersifat korelasi yang diarahkan untuk menjelaskan hubungan antara dua variabel. Desain penelitian menggunakan cross sectional dimana variabel independen dan dependen diukur secara bersamaan. Populasi dalam penelitian ini perawat yang bekerja di instalasi rawat inap RSUD Wates Kulon Progo yang terdiri dari ruang rawat inap Bougenvile, Edelweis, Flamboyan, Gardenia, dan Melati yang berjumlah 71 orang responden, karena populasi kurang dari 100 maka teknik penggambilan sampel yang digunakan adalah total sampel.

Analisis yang digunakan uji alternative Fisher's untuk mengetahui hubungan antara motivasi dengan perilaku perawat dalam mendokumentasikan asuhan keperawatan. Penelitian ini telah mendapatkan kelaikan dan persetujuan dari Komisi Etik Fakultas IImu IImu Kesehatan Universitas Alma Ata tanggal 7 Februari 2019: 079/A/SPn/Ners/Fikes/UAA/II/2019. Penelitian ini menggunakan informed consent terlebih dahulu ketika meminta kesediaan responden untuk ikut serta dalam penelitian ini. Pengumpulan data dibantu lima orang asisten penelitan dari mahasiswa keperawatan Universitas Alma Ata. Penelitian ini dilaksanakan pada bulan Maret selama 18 hari.

\section{HASIL DAN PEMBAHASAN}

Penelitian ini dilakukan di instalasi rawat inap RSUD Wates pada bulan Maret 2019 mengenai hubungan antara motivasi dengan perilaku perawat dalam mendokumentasikan asuhan keperawatan. Dengan hasil sebagai berikut:

Tabel 1 Distribusi Karakteristik Responden Berdasarkan Pendidikan, Usia, dan Lama Kerja Perawat di RSUD Wates Kulon Progo Tahun 2019 ( $\mathrm{n}=71)$

\begin{tabular}{lcc}
\hline Karakteristik responden & $\mathbf{f}$ & $\mathbf{( \% )}$ \\
\hline Pendidikan & 58 & 81,7 \\
D3 Keperawatan & 3 & 4,2 \\
D4 Keperawatan & 10 & 14,1 \\
S1 Ners & & \\
\hline Usia & 41 & 57,7 \\
21-30 Tahun & 25 & 35,2 \\
31-40 Tahun & 5 & 7,0 \\
> 40 Tahun & & \\
\hline Lama Kerja & 20 & 28,2 \\
1-3 Tahun & 24 & 33,8 \\
4-6 Tahun & 27 & 38,0 \\
$>$ 7 Tahun & 71 & 100,0 \\
\hline Jumlah &
\end{tabular}

Indonesian Journal of Hospital Administration Vol. 3 No.1 
Hasil analisis karakteristik responden berdasarkan pendidikan sebagian besar responden memiliki tingkat pendidikan D3 keperawatan sebanyak 58 orang $((81,7 \%)$, D4 keperawatan sebanyak 3 orang (4,2\%), dan S1 Ners sebanyak 10 orang (14,1\%). Menurut Taufik Effendi (7) tingkat pendidikan merupakan bagian yang besar dalam membangun kinerja yang baik sesuai dengan tujuan yang akan dicapai. Bahkan pegawai yang telah mempunyai pengalaman kerja yang cukup lama harus sering mengupdate ilmu terbaru untuk meningkatkan produktivitas kerja melalui pembinaan, pendidikan dan pelatihan.

Hasil penelitian menunjukkan bahwa responden dengan rentang usia 21 - 30 tahun lebih sebanyak 41 orang $(57,7 \%)$, rentang usia 31 - 40 sebanyak $25(35,2 \%)$ orang, dan yang mempunyai rentang usia $>40$ tahun sebanyak 5 orang $(7,0 \%)$. Penelitian ini sejalan dengan yang dipaparkan oleh Lia Fitriyanti pada tahun 2016 bahwa mayoritas yang berusia $20-30$ tahun sebanyak $52,2 \%$ dan yang berusia 34 - 34 tahun sebanyak 47,8\% sebagian besar usia perawat pada area produktif untuk meningkatkan motivasi.

Hasil penelitian berdasarkan karakteristik lama kerja menunjukkan bahwa rentang 1 - 3 tahun sebanyak 20 orang (28,2\%), $4-7$ tahun sebanyak 24 orang $(33,8 \%)$, dan $>7$ tahun sebanyak 27 orang (38,0\%). Menurut Alamsyah (12) lama kerja dapat mempengaruhi seseorang dalam melakukan pekerjaan, semakin lama masa kerja maka dari segi pelimpahan wewenang, struktur kerja serta pengupahan menjadi pertimbangan.

Tabel 2 Distribusi frekuensi berdasarkan motivasi perawat di ruang rawat inap RSUD Wates Kulon Progo

\begin{tabular}{lcc}
\hline Kategori & $\mathbf{f}$ & $\%$ \\
\hline Tinggi & 48 & 67,6 \\
Sedang & 2 & 32,4 \\
Rendah & 0 & 0 \\
\hline Jumlah & 71 & 100,0 \\
\hline
\end{tabular}

Hasil pada penelitian ini terkait motivasi perawat di instalasi rawat inap RSUD Wates Kulon Progo menunjukkan terdapat sebagian besar perawat memiliki motivasi yang tinggi sebanyak 48 orang $(67,6 \%)$, perawat yang memiliki motivasi sedang sebanyak 23 orang $(32,4 \%)$, dirumah sakit tersebut tidak terdapat perawat yang memiliki motivasi yang rendah. Menurut Chukwama \& Obiefuna (13) motivasi adalah proses yang mendorongan seseorang melakukan suatu pekerjaan sesuai dengan tujuan yang ingin dicapai. Karyawan yang memiliki motivasi tinggi cendrung akan menyelesaikan pekerjaannya sebaik mungkin.

Tabel 3 Distribusi Fekuensi berdasarkan perilaku perawat diruang rawat inap RSUD Wates Kulon Progo

\begin{tabular}{lcc}
\hline Kategori & $\mathbf{f}$ & $\%$ \\
\hline Baik & 63 & 88,7 \\
Kurang baik & 8 & 11,3 \\
\hline Jumlah & 71 & 100,0 \\
\hline
\end{tabular}

Indonesian Journal of Hospital Administration Vol. 3 No.1 
Hasil penelitian terkait perilaku perawat di instalasi rawat inap RSUD Wates Kulon progo menujukkan bahwa sebanyak 63 orang (88,7\%) memiliki perilaku baik dalam mendokumentasikan asuhan keperawatan dan yang memiliki perilaku kurang sebanyak 8 orang $(11,3 \%)$. Menurut teori perubahan yang dikemukakan oleh Lawrence Gren bahwa perubahan perilaku dapat dipengaruhi oleh tiga faktor yaitu : faktor prediposisi, faktor penguat dan faktor pendukung. Tabulasi silang hubungan antara motivasi dengan perilaku perawat dalam mendokumentasikan asuhan keperawatan di RSUD Wates Kulon Progo dapat dilihat pada tabel berikut ini :

Tabel 4 Tabulasi Silang Hubungan antara Motivasi dengan Perilaku Perawat dalam Mendokumentasikan Asuhan Keperawatan Diinstalasi Rawat Inap RSUD Wates Kulon Progo

\begin{tabular}{lcccccccc}
\hline \multirow{2}{*}{ Motivasi } & \multicolumn{8}{c}{ Perilaku } \\
\cline { 2 - 9 } & Baik & \multicolumn{1}{c}{ Kurang } & & Total & $\mathbf{X}^{\mathbf{2}}$ & Sig \\
\cline { 2 - 8 } & $\mathbf{f}$ & $\%$ & $\mathbf{f}$ & $\%$ & $\mathbf{f}$ & $\%$ & & \\
\hline Tinggi & 46 & 95,8 & 2 & 42 & 48 & 100 & 7,473 & 0,012 \\
Sedang & 17 & 73,9 & 6 & 26,1 & 23 & 100 & & \\
\hline Total & 63 & 88,7 & 8 & 11,3 & 71 & 100 & & \\
\hline
\end{tabular}

Berdasarkan hasil penelitian ini tabulasi silang antara motivasi dengan perilaku perawat didapatkan hasil bahwa sebagian besar perawat memiliki motivasi tinggi cenderung memiliki perilaku yang baik sebanyak 46 orang (95,8\%) perawat dengan motivasi sedang memiliki perilaku baik sebanyak 17 orang (73,9\%), perawat dengan motivasi tinggi memiliki perilaku kurang sebanyak 2 orang (4,2\%) sedangkan, perawat dengan motivasi sedang dengan perilaku kurang sebanyak 6 orang (26,1\%) menunjukkan adanya hubungan antara motivasi dengan perilaku perawat dalam mendokumentasiakan asuhan keperawatan dimana diperoleh nilai $p$ value 0,012 . Hal ini sejalan dengan yang dikemukan oleh Steers \& Porter bahwa motivasi adalah suatu usaha yang dapat menimbulkan perilaku, mengarahkan perilaku serta mempertahankan perilaku yang sesuai dilingkungan kerja.

Sesuai dengan teori motivasi harapan yang dikemukakan oleh Victor Vroombahwa motivasi dalam dunia kerja setiap individu mengaharapkan konsekuensi atas apa yang mereka lakukan, sehingga menimbulkan harapan yang nantinya akan mempengaruhi cara bertingkah laku dalam pekerjaan, tingkah laku tersebut tergantung dengan hasil yang diharapkan bisa berupa tanggung jawab atas pekerjaan itu sendiri atau harapan atas imbalan yang dirasakan langsung. Mutu pelayanan rumah sakit, tanggung jawab dan tanggung gugat dapat dilihat dari pelayanan yang diberikan, salah satunya adalah pendokumentasian asuhan keperawatan yang diberikan kepada pasien dan keluarga sehingga motivasi dengan perilaku sangat berpengaruh dalam pelaksanaan dokumentasi yang dilakukan. Hal ini sejalan dengan penelitian yang dilakukan oleh Sumirat Titis pada tahun 2014 bahwa motivasi yang cukup 
memiliki mutu dokumentasi yang berkategori baik sebanyak 65,8\% motivasi sangat berpengaruh terhadap kinerja seorang perawat.

Perawat akan memberikan asuhan keperawatan mulai dari pengkajian sampai dengan evaluasi karena adanya motivasi. Demikian juga dengan dokumentasi keperawatan akan lengkap dan mempunyai mutu yang baik apabila perawat mempunyai motivasi yang tinggi dalam melakukan pencatatan rekam medis pasien. Hasil uji alternative Fisher's terhadap kedua variabel didapatkan nilai sebesar 0,012, sehingga dapat disimpulkan bahwa semakin tinggi motivasi maka akan semakin baik pula perilaku perawat dalam mendokumentasikan asuhan keperawatan.

Adapun keterbatasan dalam penelitian ini diantaranya adalah : waktu dinas yang berbeda-beda tiap perawat dan jarak yang ditempuh selama penelitian cukup jauh. Hasil penelitian ini diharapkan dapat bermanfaat dalam dunia kesehatan terutama dibidang keperawatan sebagai gambaran, acuan dan evaluasi terkait motivasi dengan perilaku perawat dalam mendokumentasikan asuhan keperawatan dalam mendokumentasikan asuhan keperawatan.

\section{SIMPULAN DAN SARAN}

Motivasi perawat di instalasi rawat inap RSUD Wates Kulon Progo sebagian besar memiliki kategori motivasi tinggi sebanyak 48 orang $(67,6 \%)$. Perilaku perawat di instalasi rawat inap RSUD Wates Kulon Progo sebagian besar memiliki kategori baik dalam mendokumentasikan asuhan keperawatan sebanyak 63 orang (88,7\%). Terdapat hubungan yang signifikan antara motivasi dengan perilaku perawat dalam mendokumentasikan asuhan keperawatan di instalasi rawat inap RSUD Wates Kulon Progo. Sehingga apabila motivasi perawat tinggi maka perilaku dalam mendokumentasikan asuhan keperawatan juga akan baik.

\section{DAFT AR PUSTAKA}

1. Hussainat Taiye, B. Knowledge and Practice of Documentation among Nurses in. IOSR Journal of Nursing and Health Science Ver. I, 46, 2320-1940. https://doi.org/10.9790/1959-04610106; 2015.

2. Amalia, Amalia, Hema Malini, and Sri Yulia. Kepuasan Perawat Terhadap Kualitas Pendokumentasian Asuhan Keperawatan Berbasis Komputer. Jurnal Keperawatan Indonesia 21.3: 169-179.2018.

3. Siswanto Sastrowijoto, S. T. K. K. (2013). Implementasi Pemenuhan Hak Dan Kewajiban Perawat Di Rumah Sakit Umum Daerah Rokan Hulu Berdasarkan Peraturan Menteri Kesehatan Republik Indonesia Nomor 148 Tahun 2010 Tentang Izin Dan Penyelenggaraan Praktik Perawat (Doctoral dissertation, [Yogyakarta]: Universitas Indonesian Journal of Hospital Administration Vol. 3 No.1 
Gadjah Mada).

4. Kurniawandari, Erna, Fatma Siti Fatimah, and Mutiara Dewi Listiyanawati. Implementation of Documentation of Nursing Care in Wates Hospital. Jurnal Ners dan Kebidanan Indonesia $\quad 6.2 \quad: \quad 68-75.2019 . \quad$ Available from: https://ejournal.almaata.ac.id/index.php/JNKI/article/view/955/pdf1.

5. Yanti, R. I., \& Warsito, B. E. Hubungan Karakteristik Perawat, Motivasi, dan Supervisi dengan Kualitas Dokumentasi Proses Asuhan Keperawatan Retyaningsih Ida Yanti, Bambang Edi Warsito; 2013.

6. Machfoed, Ircham. Metodologi Penelitian (Kuantitatif \& Kualitatif). Edisi revisi. Yogyakarta: Fitramaya; 2014.

7. Sugiyono. Metode penelitian kuantitatif kualitatif dan R\&D. Bandung: Alfabeta; 2011.

8. Mulyanti. Dokumentasi Keperawatan. Jakarta : Trans Info Media Dharma; 2015.

9. Taufik Effendi. Pengaruh Kompetensi, Independensi, dan Motivasi Terhadaop Kualitas Audit Aparat Inspektorat dalam Pengawasan Keuangan Daerah [Jurnal] Program Studi Magister Sains Akuntansi, Universitas Dipenogoro. 2010.

10. Notoatmodjo, S. Pendidikan dan Perilaku Kesehatan. Jakarta : Rineka Cipta 2014

11. Steers, R.M. and Porter, L.W. Motivation and Work Behavior. New York: Mc Graw-Hill Book Company 2010.

12. Wibowo. Manajemen Kerja.Edisi ke 3. Jakarta: Rajawali Pres; 2013.

13. Titis S. Hubungan Motivasi Kerja Perawat dengan Mutu Pendokumentasian Asuhan Keperawatan diruang Rawat Inap Penyakit Dalam Panembahan Senopati Bantul [Naskah Publikasi] Yogyakarta: Sekolah Tinggi Ilmu Kesehatan 'Aisyiyah, 2014.

14. Akhmadi P, Alamsyah A, Noermijati. Pengaruh Kompensasi dan Kepuasan Kerja Terhadap Komitmen Organisasi Perawat dan BIDAN Kontrak di RS Bhayangkara Hasta Brata Batu Malang. Jurnal Aplikasi Manajemen. Vol 14 No.12016.

15. Chukwuma, E.M., \& Obiefuna, O. Effect of Motivation on Employee Productivity: A Study of Manufacturing Companies. Journal of Mnagerial Studies and Reserch Vol 2 No,7 2014. 